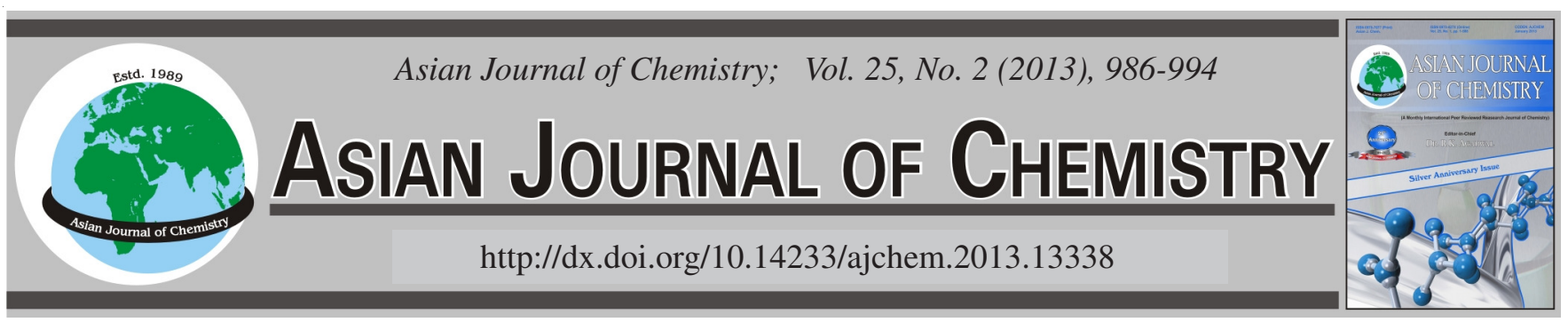

\title{
Synthesis of Azabicyclo[3.1.0]amine Analogues of Anacardic Acid as Potent Antibacterial Agents
}

\author{
Ravi Kumar Vempati ${ }^{1}$, N.S. Reddy ${ }^{1}$, Srinivasa Rao Alapati ${ }^{1, *}$ and P.K. Dubey ${ }^{2}$
}

\begin{abstract}
${ }^{1}$ Medicinal Chemistry Division, GVKBIO Sciences Pvt. Ltd., IDA-Uppal, Hyderbad-500 039, India
${ }^{2}$ Department of Chemistry, Jawaharlal Nehru Technological University, Hyderabad-500 072, India

*Corresponding author: E-mail: asrinivas@gvkbio.com
\end{abstract}

\begin{abstract}
Azabicyclo[3.1.0] amine analogues of anacardic acid (16a, 16b, 18a, 18b, 19 and 19b) were synthesized from anacardic acid and tested for their antibacterial activity against Gram positive and Gram negative bacteria. Most of the compounds are having potency at par with ampicillin and inferior with other standard drugs.
\end{abstract}

Key Words: Cashew nut shell liquid, Anacardic acid, Trovofloxacin, Azabicyclo[3.1.0]amine analogues, Antibacterial activity.

ᄂ _ - - - - - - - - - - - - - - - - - - - - - - - - - - - - -

\section{INTRODUCTION}

The emerging resistance of microorganisms to known antibiotics is creating a situation to develop novel antibiotics. Therefore, designing and innovating drugs could be the choice to meet the ongoing demand for novel antibiotics. These novel antibiotics should be identified either from natural products or synthetic compounds. Due to weak biological activity, some of the natural products were remained useless. As part of this developing novel antibiotics, the milder natural products could be converted as potential drug candidates by making necessary structural modifications.

Anacardic acid is a natural product that can be isolated from cashew nut shell liquid (CNSL), usually available as an ene-mixture (Fig. 1). Cashew nut shell liquid contains anacardic acid ene-mixture along with salicylic acid and a non-isoprenoid long alk(en)yl side chain moiety ${ }^{1,2}$. Anacardic acid is thought to possess its antibacterial activity due to its long alkyl chain ${ }^{3}$. The anacardic acid ene-mixture is composed of a long C15alkyl side chain with monoenoic, dienoic and trienoic at the C-8, C-11 and C-14 positions respectively (Fig. 1). Anacardic acid and its derivatives have been reported to possess a range of bioactivities such as antibacterial action against Methicillin resistant Staphylococcus aureus (MRSA) ${ }^{4}$.

Earlier several researchers have carried out their work on anacardic acid and its derivatives for different therapeutic purposes for inhibition of triglycerides ${ }^{5}$, ureil soybean lipoxygenase-1 inhibition ${ }^{6}$, Sildenafil analogues ${ }^{7}$, dihydropyridine analogues as calcium channel blockers ${ }^{8}$, isonicotinoylhydrazones for antimycobacterial activity ${ }^{9}$, bioactivity against
Colarado potato beetle ${ }^{10}$, modulation of nuclear factor Kappa $\beta$ signalling pathway by inhibit acetyl transferase in suppression of nuclear factor $\beta^{11}$, cytotoxic activity on BT-20 breast and Hela epithelioid cervix carcinoma cells ${ }^{12}$, zoosporicidal activity against Aphanomyces cochlioides ${ }^{13}$, kinase activity of Aurora kinase $A^{14}$, benzamide derivatives for HAT activation ${ }^{15}$ and inhibition of the acetyl histone transferase $\mathrm{PCAF}^{16}$.<smiles>CCCCCCCCCCCCCCCc1cccc(O)c1C(=O)O</smiles>

1a (anacardic acid)

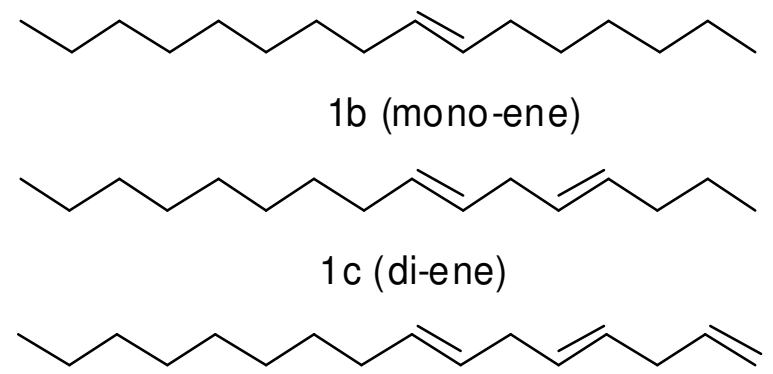

$1 \mathrm{~d}$ (tri-ene)

Fig. 1. Anacardic acid and its ene-mixture 
In our previous communication ${ }^{16}$, we have reported the synthesis of novel benzylamine analogues of anacardic acid and tested for their antibacterial activity against $S$. aureus and S. pyogens (Gram positive) and E. Coli and P. aeruginosa (Gram negative) groups of bacteria. As part of this program, this time we have chosen to utilize the azabicyclo[3.1.0]amine, which is part of known antibiotic drug (i.e.) Trovafloxacin (Trovan) (Fig. 2).<smiles>N[C@H]1[C@@H]2CN(c3cc4c(cc3F)c(=O)c(C(=O)O)cn4-c3ccc(F)cc3F)C[C@H]12</smiles>

Fig.2. Trovafloxacin

Trovofloxacin is a new synthetic antibacerial fluoro quinoline which exhibits high potency against a broad spectrum of Gram (-ve) and Gram (+ve) bacteria. Among the fluoroquinolines, trovafloxacin was found most active ( $\mathrm{MIC}_{90}$, $1 \mu \mathrm{g} / \mathrm{mL})$, followed by Sparfloxacin $\left(\mathrm{MIC}_{90}, 8 \mu \mathrm{g} / \mathrm{mL}\right)$, Levofloxacin ( $\mathrm{MIC}_{90}, 16 \mu \mathrm{g} / \mathrm{mL}$ ), Ofloxacin ( $\mathrm{MIC}_{90}, 32 \mu \mathrm{g}$ / $\mathrm{mL})$. Ciprofloxacin was the least active quinoline $\left(\mathrm{MIC}_{90}, 64\right.$ $\mu \mathrm{g} / \mathrm{mL})^{17}$.

Hence, we have chosen to couple the azabicyclo[3.1.0] amine with derivatives of anacardic acid and synthesized the compounds as depicted in Figs. 3 and 4. The synthesized targets were screened for their antibacterial activity against $E$. coli, $P$. aeruginosa, $S$. aureus and $S$. pyogens, while using ampicillin, chloramphenicol, ciprofloxacin and norfloxacin as the standard drugs.

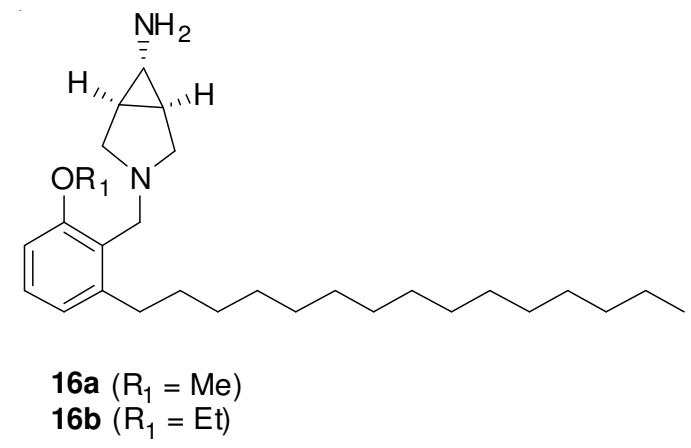

Fig. 3. Compounds 16a and $\mathbf{1 6 b}$

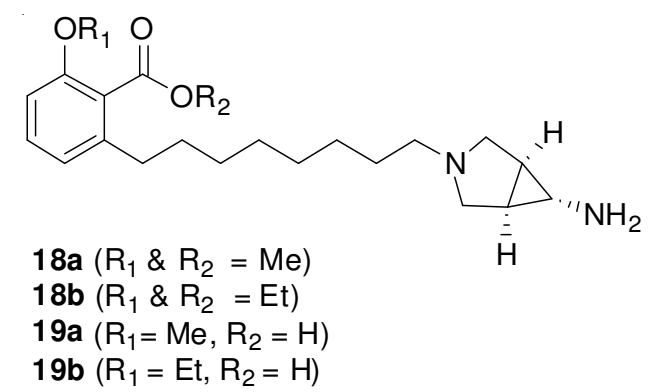

Fig. 4. Compounds 18a, 18b, 19a and 19b

\section{EXPERIMENTAL}

The reagents and solvents used in this study were of analytical grade and were used without further purification. Melting points were determined in open capillaries and are uncorrected. Thin-layer chromatography was used for reaction monitoring using silica gel $\mathrm{GF}_{254}$ and spots were detected using iodine chamber or UV lamp at $254 \mathrm{~nm}$. IR were recorded on FTIR Perkin elmer spectrometer and the ${ }^{1} \mathrm{H}$ NMR spectra on a Varian EM-360 spectrometer (400 MHz) using TMS as an internal standard. The mass spectra were recorded on Agilent ion trap MS. All the products were characterized by IR, ${ }^{1} \mathrm{H}$ NMR (400 $\mathrm{MHz}$ ), Mass analysis. All compounds were purified by either column chromatography or recrystallization techniques. IUPAC names were generated using Chemdraw 11.0 computer program.

Preparation of anacardic acid (1a-1d, ene-mix): To a solution of $\mathrm{MeOH}(6 \mathrm{vol})$ and $\mathrm{H}_{2} \mathrm{O}$ (1 vol) containing commercial grade CNSL $(100 \mathrm{~g})$, was added $\mathrm{Ca}(\mathrm{OH})_{2}(50 \mathrm{~g})$ and the contents were heated to $60^{\circ} \mathrm{C}$ for $3 \mathrm{~h}$. The precipitated solid was filtered and the wet cake was washed with $\mathrm{MeOH}$ (1 vol) to remove the cardol and cardanol. The brown coloured precipitate was then suspended in water, $\mathrm{pH}$ was adjusted to 2 range using $6 \mathrm{~N} \mathrm{HCl}$ solution under vigorous stirring and extracted with ethyl acetate $(3 \times 200 \mathrm{~mL})$. The combined organic layer was washed with $\mathrm{H}_{2} \mathrm{O}$, brine solution, dried over anhydrous $\mathrm{Na}_{2} \mathrm{SO}_{4}$, concentrated to dryness to afford the anacardic acid ene-mixture as dark-brown coloured viscous oil (60 g, crude).

Preparation of anacardic acid (2): To a solution of ethanol (700 mL) containing the ene-mixture (1a-1d) (60 g, crude) $10 \% \mathrm{Pd} / \mathrm{C}(6 \mathrm{~g})$ was slowly added under inert atmosphere into a hydrogenation flask. Hydrogenation was carried out under 60 psi of hydrogen pressure for $2 \mathrm{~h}$. Filtered the contents through a pad of celite to remove the catalyst, collected the clear filtrate, concentrated under reduced pressure to afford the crude anacardic acid (2), which was recrystallized from petroleum ether $\left(40-60{ }^{\circ} \mathrm{C}\right)$; Yield $36 \mathrm{~g}$; m.p. 85-86 ${ }^{\circ} \mathrm{C}$; IR $\left(\mathrm{KBr}, \mathrm{v}_{\max }, \mathrm{cm}^{-1}\right)$ : 3071, 3002, 2917, 1655, 1450, 1246, 1214, 894, 815, 757; ${ }^{1} \mathrm{H}$ NMR (400 MHz, $\mathrm{CDCl}_{3}$ ): $\delta 11.02$ (br s, $1 \mathrm{H}), 7.36(\mathrm{t}, J=8.0 \mathrm{~Hz}, 1 \mathrm{H}), 6.88(\mathrm{~d}, J=8.4 \mathrm{~Hz}, 1 \mathrm{H}), 6.78(\mathrm{~d}$, $J=7.6 \mathrm{~Hz}, 1 \mathrm{H}), 2.98(\mathrm{t}, J=8.0 \mathrm{~Hz}, 2 \mathrm{H}), 1.57-1.63(\mathrm{~m}, 3 \mathrm{H})$, 1.27 (br s, 23H), 0.88 (t, $J=6.8 \mathrm{~Hz}, 3 \mathrm{H}$ ); Mass: $m / z$ : 349 $(\mathrm{M}+\mathrm{H})^{+}$.

Preparation of methyl-2-methoxy-6-pentadecylbenzoate (3a): To a stirred solution of compound 2 ( $26 \mathrm{~g}, 0.074$ $\mathrm{mmol})$ in acetonitrile $(250 \mathrm{~mL})$ was added powdered anhydrous $\mathrm{K}_{2} \mathrm{CO}_{3}(41 \mathrm{~g}, 0.30 \mathrm{~mol})$, followed by dimethyl sulfate $(28 \mathrm{~mL}$, $0.30 \mathrm{mmol}$ ) in portions for about $15 \mathrm{~min}$ at room temperature. The contents were heated at $80{ }^{\circ} \mathrm{C}$ for $3 \mathrm{~h}$, cooled to room temperature, filtered, and the clear filtrate was concentrated under reduced pressure and the residue was diluted with water $(150 \mathrm{~mL})$, extracted with EtOAc $(2 \times 100 \mathrm{~mL})$. The combined organic layer was washed with water, brine solution, dried over anhydrous $\mathrm{Na}_{2} \mathrm{SO}_{4}$, concentrated to afford the compound 3a as a low-melting solid. m.p. 37-38 ${ }^{\circ} \mathrm{C}$, Yield: $22 \mathrm{~g}(78 \%)$; IR $\left(\mathrm{KBr}, v_{\max }, \mathrm{cm}^{-1}\right): 3004,2921,2852,1732,1589,1266$, 1105; ${ }^{1} \mathrm{H} \mathrm{NMR}\left(400 \mathrm{MHz}, \mathrm{CDCl}_{3}\right): \delta 7.25(\mathrm{t}, J=8.0 \mathrm{~Hz}, 1 \mathrm{H})$, $6.82(\mathrm{~d}, J=8.0 \mathrm{~Hz}, 1 \mathrm{H}), 6.75(\mathrm{~d}, J=8.4 \mathrm{~Hz}, 1 \mathrm{H}), 3.90(\mathrm{~s}, 3 \mathrm{H})$, $3.81(\mathrm{~s}, 3 \mathrm{H}), 2.53$ (t, $J=8.0 \mathrm{~Hz}, 2 \mathrm{H}), 1.53-1.60(\mathrm{~m}, 3 \mathrm{H}), 1.27$ (brs, $23 \mathrm{H}), 0.88(\mathrm{t}, J=6.8 \mathrm{~Hz}, 3 \mathrm{H})$; Mass: $m / z: 377(\mathrm{M}+\mathrm{H})^{+}$. 
Preparation of ethyl-2-ethoxy-6-pentadecylbenzoate (3b): To a stirred solution of compound $2(26 \mathrm{~g}, 0.074 \mathrm{mmol})$ in acetonitrile $(250 \mathrm{~mL})$ was added powdered anhydrous $\mathrm{K}_{2} \mathrm{CO}_{3}(41 \mathrm{~g}, 0.30 \mathrm{~mol})$, followed by diethyl sulfate $(39 \mathrm{~mL}$, $0.30 \mathrm{mmol}$ ) in portions for about $15 \mathrm{~min}$ at room temperature. The contents were heated at $80{ }^{\circ} \mathrm{C}$ for $3 \mathrm{~h}$, cooled to room temperature, filtered, collected the filtrate, concentrated under reduced pressure and the residue was diluted with water $(150 \mathrm{~mL})$, extracted with EtOAc $(2 \times 100 \mathrm{~mL})$. The combined organic layer was washed with water, brine solution, dried over anhydrous $\mathrm{Na}_{2} \mathrm{SO}_{4}$, concentrated to afford the compound 3b as a low-melting solid. m.p. $57-59^{\circ} \mathrm{C}$, Yield: $23 \mathrm{~g}(76 \%)$; IR (KBr, $\left.v_{\max }, \mathrm{cm}^{-1}\right)$ : 2982, 2926, 2854, 1729, 1585, 1462, 1395, 1268, 1196, 1111, 1069, 1007, 921, 825; ${ }^{1} \mathrm{H}$ NMR (400 $\left.\mathrm{MHz}, \mathrm{CDCl}_{3}\right): \delta 7.22(\mathrm{t}, J=8.2 \mathrm{~Hz}, 1 \mathrm{H}), 6.79(\mathrm{~d}, J=8.0 \mathrm{~Hz}$, $1 \mathrm{H}), 6.73(\mathrm{~d}, J=8.0 \mathrm{~Hz}, 1 \mathrm{H}), 4.41-4.31(\mathrm{~m}, 4 \mathrm{H}), 2.54(\mathrm{t}, J=$ $8.0 \mathrm{~Hz}, 2 \mathrm{H}), 1.59-1.55$ (m, 3H), 1.45-1.35 (m, 6H), 1.27-1.24 $(\mathrm{m}, 23 \mathrm{H}), 0.88(\mathrm{t}, J=6.4 \mathrm{~Hz}, 3 \mathrm{H})$; Mass: $m / z: 405.2(\mathrm{M}+\mathrm{H})^{+}$.

Preparation of 2-methoxy-6-pentadecylphenyl)methanol (4a): To a stirred suspension of $\mathrm{LiAlH}_{4}(3.3 \mathrm{~g}, 88 \mathrm{mmol})$ in dry THF $(100 \mathrm{~mL})$ was added the solution of compound 3a $(22 \mathrm{~g}, 58.5 \mathrm{mmol})$ in dry THF $(50 \mathrm{~mL})$ at $-20^{\circ} \mathrm{C}$ and allowed the contents to $\mathrm{rt}$ and stirred for $16 \mathrm{~h}$. The reaction mixture was quenched with saturated $\mathrm{NH}_{4} \mathrm{Cl}$ solution, filtered through a pad of celite, collected the filtrate, concentrated to dryness. The residue was dissolved in EtOAc, washed with $\mathrm{H}_{2} \mathrm{O}$, brine solution, dried and concentrated to afford the crude compound 4a as pale brown coloured solid (15 g, $73.6 \%)$; m.p. 59-60 ${ }^{\circ} \mathrm{C}$; IR $\left(\mathrm{KBr}, \mathrm{v}_{\max }, \mathrm{cm}^{-1}\right)$ : 3386, 3072, 2916, 2846, 1705, 1461, 1265, 1118 and 1076; ${ }^{1} \mathrm{H}$ NMR (400 MHz, $\left.\mathrm{CDCl}_{3}\right): \delta 7.20(\mathrm{t}$, $J=8.0 \mathrm{~Hz}, 1 \mathrm{H}), 6.82(\mathrm{~d}, J=7.6 \mathrm{~Hz}, 1 \mathrm{H}), 6.77(\mathrm{~d}, J=8.0 \mathrm{~Hz}$, $1 \mathrm{H}), 4.75(\mathrm{~d}, J=6.4 \mathrm{~Hz}, 2 \mathrm{H}), 3.87(\mathrm{~s}, 3 \mathrm{H}), 2.67(\mathrm{t}, J=6.4 \mathrm{~Hz}$, 2H), 2.37 (t, $J=6.4 \mathrm{~Hz}, 2 \mathrm{H}), 1.53-1.58(\mathrm{~m}, 3 \mathrm{H}), 1.27$ (br s, $23 \mathrm{H}), 0.89$ (t, $J=7.2 \mathrm{~Hz}, 3 \mathrm{H})$; Mass: $m / z: 349(\mathrm{M}+\mathrm{H})^{+}$.

Preparation of 2-ethoxy-6-pentadecylphenyl)methanol (4b): To a stirred suspension of $\mathrm{LiAlH}_{4}(3.3 \mathrm{~g}, 88 \mathrm{mmol})$ in dry THF $(100 \mathrm{~mL})$ was added the solution of compound $\mathbf{3 b}$ $(23.6 \mathrm{~g}, 58.5 \mathrm{mmol})$ in dry THF $(50 \mathrm{~mL})$ at $-20{ }^{\circ} \mathrm{C}$ and allowed the contents to rt and stirred for $16 \mathrm{~h}$. The reaction mixture was quenched with saturated $\mathrm{NH}_{4} \mathrm{Cl}$ solution, filtered through a pad of celite, collected the filtrate, concentrated to dryness. The residue was dissolved in EtOAc, washed with $\mathrm{H}_{2} \mathrm{O}$, brine solution, dried and concentrated to afford the crude compound $\mathbf{4 b}$ as pale brown coloured solid (16 g, $75.6 \%$ ); m.p. $59-60{ }^{\circ} \mathrm{C}$; IR $\left(\mathrm{KBr}, v_{\max }, \mathrm{cm}^{-1}\right)$ : 3380, 3065, 2846, 1701, 1460, 1270, 1125, 1080 and 850; ${ }^{1} \mathrm{H} \mathrm{NMR}\left(400 \mathrm{MHz}, \mathrm{CDCl}_{3}\right)$ : $\delta 7.22(\mathrm{t}, J=8.2 \mathrm{~Hz}, 1 \mathrm{H}), 6.86(\mathrm{~d}, J=7.6 \mathrm{~Hz}, 1 \mathrm{H}), 6.77(\mathrm{~d}, J=$ $7.6 \mathrm{~Hz}, 1 \mathrm{H}), 4.25-4.07(\mathrm{~m}, 4 \mathrm{H}), 3.87(\mathrm{~s}, 1 \mathrm{H}), 2.67(\mathrm{t}, J=6.4$ $\mathrm{Hz}, 2 \mathrm{H}), 1.53-1.58$ (m, 3H), 1.27 (br s, 26H), 0.89 (t, $J=7.2$ $\mathrm{Hz}, 3 \mathrm{H})$; Mass: $m / z: 363(\mathrm{M}+\mathrm{H})^{+}$.

Preparation of methane sulfonate esters (5a and 5b): To a stirred solution of compound $\mathbf{4 a}$ (or) $\mathbf{4 b}(0.15 \mathrm{~mol})$ in $\mathrm{CH}_{2} \mathrm{Cl}_{2}(50 \mathrm{~mL})$ was added $\mathrm{Et}_{3} \mathrm{~N}(0.45 \mathrm{~mol})$ and cooled to $0{ }^{\circ} \mathrm{C}$. To this mixture was added methanesulfonylchloride $(0.225 \mathrm{~mol})$ at $0{ }^{\circ} \mathrm{C}$ over a period of $15 \mathrm{~min}$. The contents were allowed to warm to $\mathrm{rt}$ and stirred for $4 \mathrm{~h}$. The reaction mixture was diluted with water and extracted with $\mathrm{CH}_{2} \mathrm{Cl}_{2}(2 \times$ $50 \mathrm{~mL}$ ). The organic layer was washed with brine solution, dried over anhydrous $\mathrm{Na}_{2} \mathrm{SO}_{4}$, concentrated to dryness to afford the crude compounds $\mathbf{5 a}$ or $\mathbf{5 b}$ as pale brown coloured solids. The crude products were used as such in the step without further purification.

Preparation of methyl 2-methoxy-6-((8E,11E)pentadeca-8,11,14-trienyl)benzoate (6a): To a solution of 1a-1d ( $65 \mathrm{~g}, 0.19 \mathrm{mmol})$ in acetonitrile was added $\mathrm{K}_{2} \mathrm{CO}_{3}(105$ $\mathrm{g}, 0.76 \mathrm{~mol})$ followed by dimethyl sulfate $(44.5 \mathrm{~mL}, 0.47 \mathrm{~mol})$ and heated at $65^{\circ} \mathrm{C}$ for $5 \mathrm{~h}$. The reaction mixture was cooled to room temperature, filtered and washed with ethyl acetate. The filtrate was concentrated and the residue was dissolved in ethyl acetate $(300 \mathrm{~mL})$. The organic layer was washed with water, brine solution and dried over anhydrous sodium sulphate and evaporated under reduced pressure. The obtained crude compound was purified by 60-120 silica-gel column chromatography (eluted with $5 \%$ ethyl acetate: pet ether) to afford $6 \mathbf{a}$ (Yield: $59 \mathrm{~g}$, pale yellow liquid) and the semi-pure product was used as such in the next step.

Preparation of ethyl 2-ethoxy-6-[(8E, 11E)-pentadeca8,11,14-trienyl]benzoate (6b): To a solution of 1a-1d (65 g, $0.19 \mathrm{~mol})$ in acetonitrile was added $\mathrm{K}_{2} \mathrm{CO}_{3}(105 \mathrm{~g}, 0.76 \mathrm{~mol})$ followed by diethyl sulfate $(62 \mathrm{~mL}, 0.47 \mathrm{~mol})$ and heated at $65^{\circ} \mathrm{C}$ for $5 \mathrm{~h}$. The reaction mixture was cooled to room temperature, filtered and washed with ethyl acetate. The filtrate was concentrated and the residue was dissolved in ethyl acetate $(300 \mathrm{~mL})$. The organic layer was washed with water, brine solution and dried over anhydrous sodium sulphate and evaporated under reduced pressure. The obtained crude compound was purified by 60-120 silica-gel column chromatography (eluted with $5 \%$ ethyl acetate: pet ether) to afford $\mathbf{6 b}$ (Yield: $60 \mathrm{~g}$, pale yellow liquid) and the semi-pure product was used as such in the next step with out further purification.

Preparation of methyl-2-(8-hydroxyoctyl)-6-methoxybenzoate (7a): To a chilled solution of $\mathbf{6 a}(15 \mathrm{~g}, 0.40 \mathrm{~mol})$ in a mixture of dichloromethane: methanol $(1: 1,500 \mathrm{~mL})$ at -78 ${ }^{\circ} \mathrm{C}$, a stream of ozone gas was passed till the reaction was completed and excess ozone gas was expelled though a stream of $\mathrm{O}_{2}$ at $-78^{\circ} \mathrm{C}$. To this mixture was added the solution of dimethyl sulfide (catalytic qty) at $-78{ }^{\circ} \mathrm{C}$ and allowed to stir at room temperature for $2 \mathrm{~h}$. The reaction mixture was again cooled to $-30{ }^{\circ} \mathrm{C}$ and sodium borohydride $(10 \mathrm{~g}, 0.26 \mathrm{~mol})$ was added portion wise over a period of $1 \mathrm{~h}$ and allowed to stir at room temperature for overnight. To the reaction mixture ice-cold water $(400 \mathrm{~mL})$ was added slowly and separated the organic layer. The aqueous layer was extracted with dichloromethane $(2 \times 200 \mathrm{~mL})$. The combined organic layer was washed with brine solution $(150 \mathrm{~mL})$ dried over anhydrous sodium sulphate, concentrated to dryness and the residue was purified by neutral alumina column chromatography (eluted with $20 \%$ ethyl acetate: pet ether) to afford 7a (Yield: $6.6 \mathrm{~g}, 55.4 \%$, yellow viscous liquid); IR (DCM film, $\mathrm{cm}^{-1}$ ): 3409, 2930, 2855, 1728, 1588, 1466, 1442, 1269, 1109, 1070, 958, 737; ${ }^{1} \mathrm{H}$ NMR (400 $\left.\mathrm{MHz}, \mathrm{CDCl}_{3}\right): \delta$ 7.26-7.28 (m, 1H); $6.82(\mathrm{~d}, 1 \mathrm{H}, J=7.6 \mathrm{~Hz})$, $6.75(\mathrm{~d}, 1 \mathrm{H}, J=8.4 \mathrm{~Hz}), 3.90(\mathrm{~s}, 3 \mathrm{H}), 3.81(\mathrm{~s}, 3 \mathrm{H}), 3.63(\mathrm{t}, 2 \mathrm{H}$, $J=6.8 \mathrm{~Hz}), 2.53(\mathrm{t}, 2 \mathrm{H}, J=8.0 \mathrm{~Hz}), 1.53-1.59(\mathrm{~m}, 4 \mathrm{H}), 1.31$ (bs, 8H); Mass: $295(\mathrm{M}+\mathrm{H})^{+}$.

Preparation of ethyl-2-ethoxy-6-(8-hydroxyoctyl)benzoate (7b): To a chilled solution of $6 \mathbf{b}(15 \mathrm{~g}, 0.37 \mathrm{~mol})$ in a mixture of dichloromethane: methanol $(1: 1,500 \mathrm{~mL})$ at $-78^{\circ} \mathrm{C}$, a stream of Ozone gas was passed till the reaction was 
completed and excess ozone gas was expelled though a stream of $\mathrm{O}_{2}$ at $-78^{\circ} \mathrm{C}$. To this mixture was added dimethyl sulfide (catalytic qty) at $-78^{\circ} \mathrm{C}$ and allowed to stir at room temperature for $2 \mathrm{~h}$. The reaction mixture was again cooled to $-30{ }^{\circ} \mathrm{C}$ and sodium borohydride ( $10 \mathrm{~g}, 0.26 \mathrm{~mol})$ was added portion wise over a period of $1 \mathrm{~h}$ and allowed to stir at room temperature for overnight. To the reaction mixture ice-cold water $(400 \mathrm{~mL})$ was added slowly and separated the organic layer. The aqueous layer was extracted with dichloromethane $(2 \times 200 \mathrm{~mL})$. The combined organic layer was washed with brine solution $(150 \mathrm{~mL})$ dried over anhydrous sodium sulphate, concentrated to dryness and the residue was purified by neutral alumina column chromatography (eluted with $20 \%$ ethyl acetate: pet ether) to afford 7b (Yield: $6.5 \mathrm{~g}, 53.7 \%$, yellow viscous liquid); IR (DCM film, $\mathrm{cm}^{-1}$ ): 3423, 2929, 2858, 1725, 1587, 1462, $1389,1266,1109,1066,758 ;{ }^{1} \mathrm{H}$ NMR $\left(400 \mathrm{MHz}, \mathrm{CDCl}_{3}\right): \delta$ 7.26-7.20 (m, 1H); $6.79(\mathrm{~d}, J=7.6 \mathrm{~Hz}, 1 \mathrm{H}), 6.73(\mathrm{~d}, J=8.0$ $\mathrm{Hz}, 1 \mathrm{H}), 4.38$ (q, $J=7.2 \mathrm{~Hz}, 2 \mathrm{H}), 4.03$ (q, $J=7.0 \mathrm{~Hz}, 2 \mathrm{H})$, $3.62(\mathrm{t}, J=6.6 \mathrm{~Hz}, 2 \mathrm{H}), 2.54(\mathrm{t}, J=8.0 \mathrm{~Hz}, 2 \mathrm{H}), 1.59-1.53(\mathrm{~m}$, $4 \mathrm{H}), 1.39-1.32(\mathrm{~m}, 14 \mathrm{H})$; Mass: $323(\mathrm{M}+\mathrm{H})^{+}$.

Preparation of methyl 2-(8-bromooctyl)-6-methoxybenzoate (8a): To a solution of $7 \mathbf{a}(15 \mathrm{~g}, 0.51 \mathrm{~mol})$ in dichloromethane $(150 \mathrm{~mL})$, cooled to $0{ }^{\circ} \mathrm{C}$ was added dry pyridine $(42 \mathrm{~mL}, 0.51 \mathrm{~mol})$ followed by triphenylphosphine $(22.7 \mathrm{~g}, 0.86 \mathrm{~mol})$. To the reaction mixture was added carbon tetrabromide $(25.4 \mathrm{~g}, 0.76 \mathrm{~mol})$, portion wise over a period of $15 \mathrm{~min}$ and stirred at room temperature for $6 \mathrm{~h}$. The reaction mixture was diluted with dichloromethane $(100 \mathrm{~mL})$, washed with $2 \mathrm{~N} \mathrm{HCl}(2 \times 150 \mathrm{~mL})$, water $(200 \mathrm{~mL})$, brine solution $(175 \mathrm{~mL})$, dried over anhydrous $\mathrm{Na}_{2} \mathrm{SO}_{4}$, filtered and evaporated under vacuum. The crude compound was purified by 100-200 silica column chromatography (eluted with $10 \%$ ethyl acetate: pet ether) to obtain $\mathbf{8 a}$ (Yield: $16 \mathrm{~g}, 88 \%$; pale brown viscous liquid); IR (DCM film, $\mathrm{cm}^{-1}$ ): 3003, 2930, 2856, 1733, 1584, 1470, 1437, 1267, 1111, 1074, 959, 748; ${ }^{1} \mathrm{H}$ NMR (400 $\left.\mathrm{MHz} ; \mathrm{CDCl}_{3}\right): \delta 7.26(\mathrm{t}, J=8.0 \mathrm{~Hz}, 1 \mathrm{H}), 6.81(\mathrm{~d}, J=7.2 \mathrm{~Hz}$, $1 \mathrm{H}), 6.76(\mathrm{~d}, J=8.0 \mathrm{~Hz}, 1 \mathrm{H}), 3.90(\mathrm{~s}, 3 \mathrm{H}), 3.82(\mathrm{~s}, 3 \mathrm{H}), 3.40$ $(\mathrm{t}, J=6.8 \mathrm{~Hz}, 2 \mathrm{H}), 2.53(\mathrm{t}, J=8.0 \mathrm{~Hz}, 2 \mathrm{H}), 1.87-1.80(\mathrm{~m}, 2 \mathrm{H})$, $1.59-1.53(\mathrm{~m}, 2 \mathrm{H}), 1.42-1.37(\mathrm{~m}, 2 \mathrm{H}), 1.33-1.30(\mathrm{~m}, 6 \mathrm{H})$; Mass: $357(\mathrm{M}+\mathrm{H})^{+}$and $359(\mathrm{M}+2,100)$.

Preparation of ethyl 2-(8-bromooctyl)-6-ethoxybenzoate (8b): To a solution of $7 \mathbf{b}(15 \mathrm{~g}, 0.51 \mathrm{~mol})$ in dichloromethane $(150 \mathrm{~mL})$, cooled to $0{ }^{\circ} \mathrm{C}$ was added dry pyridine $(42 \mathrm{~mL}$, $0.51 \mathrm{~mol})$ followed by triphenylphosphine $(22.73 \mathrm{~g}, 0.86 \mathrm{~mol})$. To the reaction mixture was added carbon tetrabromide ( $25.4 \mathrm{~g}$, $0.76 \mathrm{~mol}$ ), portion wise over a period of $15 \mathrm{~min}$ and stirred at room temperature for $6 \mathrm{~h}$. The reaction mixture was diluted with dichloromethane $(100 \mathrm{~mL})$, washed with $2 \mathrm{~N} \mathrm{HCl}(2 \times$ $150 \mathrm{~mL})$, water $(200 \mathrm{~mL})$, brine solution $(175 \mathrm{~mL})$, dried over anhydrous $\mathrm{Na}_{2} \mathrm{SO}_{4}$, filtered and evaporated under vacuum. The crude compound was purified by 100-200 silica column chromatography (eluted with $10 \%$ ethyl acetate: pet ether) to obtain 8b (Yield: 14 g, $78 \%$; pale brown viscous liquid); IR (DCM film, $\mathrm{cm}^{-1}$ ): 2979, 2930, 2857, 1728, 1584, 1462, 1268, $1110,1070,852,763 ;{ }^{1} \mathrm{H}$ NMR $\left(400 \mathrm{MHz} ; \mathrm{CDCl}_{3}\right): \delta 7.22(\mathrm{t}$, $J=7.8 \mathrm{~Hz}, 1 \mathrm{H}), 6.79(\mathrm{~d}, J=7.6 \mathrm{~Hz}, 1 \mathrm{H}), 6.73(\mathrm{~d}, J=8.4 \mathrm{~Hz}$, $1 \mathrm{H}), 4.39(\mathrm{q}, J=7.2 \mathrm{~Hz}, 2 \mathrm{H}), 4.03(\mathrm{q}, J=7.0 \mathrm{~Hz}, 2 \mathrm{H}), 3.52(\mathrm{t}$, $J=6.6 \mathrm{~Hz}, 1 \mathrm{H}), 3.39(\mathrm{t}, J=6.8 \mathrm{~Hz}, 1 \mathrm{H}), 2.55(\mathrm{t}, J=8.0 \mathrm{~Hz}$, $2 \mathrm{H}), 1.87-1.71$ (m, 2H), 1.60-1.54 (m, 2H), 1.42-1.25 (m, 14 $\mathrm{H})$, Mass: $385(\mathrm{M}+\mathrm{H})^{+}$and $387(\mathrm{M}+2,100)$.
Synthesis of (1R,5S,6r)-3-benzyl-6-nitro-3-azabicyclo[3.1.0]hexane-2,4-dione (10): To a solution of bromonitromethane $(22.45 \mathrm{~g}, 160.42 \mathrm{mmol})$ in acetonitrile $(600 \mathrm{~mL})$ was added potassium carbonate $(22.14 \mathrm{~g}, 160.42 \mathrm{mmol})$, followed by dropwise addition of $\mathrm{N}$-benzylmaleimide (9) (20 g, 106.95 mmol) solution in acetonitrile $(400 \mathrm{~mL})$ over a period of $4 \mathrm{~h}$ at room temperature and stirred for $0.5 \mathrm{~h}$. After completion of the reaction, filtered the reaction mass through celite bed and washed with ethyl acetate $(500 \mathrm{~mL})$, collected the clear filtrate, solvent was evaporated to afford the crude product as black mass. The crude product was purified by silica-gel (100-200 mesh) packed column chromatography using $5 \%$ to $10 \%$ ethyl acetate-pet ether as an eluent to afford the pure compound $10(10.0 \mathrm{~g}, 38 \%)$ as off-white solid. m.p. $112-114^{\circ} \mathrm{C}$, IR $(\mathrm{KBr}$, $\left.v_{\max }, \mathrm{cm}^{-1}\right): 3086,1788,1710,1560,1397,1359,1173,1017$, 927, 883 and $721 ;{ }^{1} \mathrm{H}$ NMR (400 $\left.\mathrm{MHz}, \mathrm{CDCl}_{3}\right): \delta 7.33-7.25$ $(\mathrm{m}, 5 \mathrm{H}), 4.53(\mathrm{~s}, 2 \mathrm{H}), 4.48(\mathrm{~d}, J=1.6 \mathrm{~Hz}, 1 \mathrm{H}), 3.35(\mathrm{~d}, J=1.6$ Hz, 1H), Mass: $m / z: 245.1\left(\mathrm{M}^{+}-1\right)$.

Synthesis of (1R,5S,6r)-3-benzyl-6-nitro-3-azabicyclo[3.1.0]hexane (11): To a solution of compound $\mathbf{1 0}$ (20 g, $81.3 \mathrm{mmol})$ in dry THF $(200 \mathrm{~mL})$ was added the solution of Borane. THF complex (320 mL, $16 \mathrm{vol})$ and heated to reflux temperature for $3 \mathrm{~h}$. The reaction mass cooled to $10^{\circ} \mathrm{C}$, added methanol $(120 \mathrm{~mL})$ slowly and heated to reflux temperature for $0.5 \mathrm{~h}$. After completion of the reaction, solvent was distilled out under reduced pressure and the residue was dissolved in dichloromethane $(300 \mathrm{~mL})$, washed with water, brine solution, dried over anhydrous sodium sulphate, concentrated to dryness to afford the crude compound $\mathbf{1 1}(15.0 \mathrm{~g}, 84 \%)$ as an oil. IR (dichloromethane film, $\mathrm{cm}^{-1}$ ): 3440, 2977, 1726, 1643, 1434, 1203, 1158, 853 and $771 ;{ }^{1} \mathrm{H}$ NMR (400 MHz, DMSO- $\left.d_{6}\right): \delta$ 7.32-7.22 (m, 5H), $4.56(\mathrm{~s}, 1 \mathrm{H}), 3.59(\mathrm{~s}, 2 \mathrm{H}), 3.15-3.10(\mathrm{~m}$, 2H), 2.54-2.50 (m, 4H); Mass: $m / z: 219.2(\mathrm{M}+1)^{+}$.

Synthesis of (1R,5S,6s)-3-benzyl-3-azabicyclo[3.1.0]hexan-6-amine (12): To a solution of compound 11 (15 g, $68.8 \mathrm{mmol})$ in isopropanol $(300 \mathrm{~mL})$ was treated with $3 \mathrm{~N} \mathrm{HCl}$ ( $225 \mathrm{~mL}$ ) and zinc dust (54 g, $825.68 \mathrm{mmol}$ ) was added slowly portion wise over a period of $0.5 \mathrm{~h}$ and stirred at room temperature for $2 \mathrm{~h}$. After completion of the reaction, the reaction mass was slowly quenched with saturated $\mathrm{NaHCO}_{3}$ solution (200 mL), stirred for $0.5 \mathrm{~h}$, filtered the reaction mass through celite pad, washed with dichloromethane $(300 \mathrm{~mL})$. Collected the filtrate and the solvent was distilled out and the aqueous layer was extracted with dichloromethane $(2 \times 100 \mathrm{~mL})$. The organic layer was washed with water, brine solution, dried over anhydrous sodium sulphate, concentrated to dryness to afford the compound $\mathbf{1 2}$ (10.0 g, semi pure) as an oil. The crude compound was used as such in the next step without any further purification.

Synthesis of (1R,5S,6s)-3-benzyl-3-azabicyclo[3.1.0]hexan-6-ylcarbamate (13): To a solution of compound 12 $(10 \mathrm{~g}, 53.19 \mathrm{mmol})$ in dry dichloromethane $(100 \mathrm{~mL})$ was added $(\mathrm{BOC})_{2} \mathrm{O}(14.86 \mathrm{~g}, 69.14 \mathrm{mmol})$ drop wise, followed by addition of triethylamine $(8.05 \mathrm{~g}, 79.78 \mathrm{mmol})$ at $0{ }^{\circ} \mathrm{C}$. The contents were allowed to room temperature and stirred for $2 \mathrm{~h}$. After completion of the reaction, solvent was distilled and the residue was purified by silica gel column chromatography using $15 \%$ ethyl acetate-pet ether as an eluent to afford the pure compound $13(9.6 \mathrm{~g}, 72 \%)$ as yellow colour solid. m.p. 
$129-132{ }^{\circ} \mathrm{C}$, IR $\left(\mathrm{KBr}, v_{\max }, \mathrm{cm}^{-1}\right): 3369,2796,1688,1518$, 1284, 1250, 1167, 850, 753 and 698; ${ }^{1} \mathrm{H}$ NMR (400 MHz, DMSO- $\left.d_{6}\right): \delta 7.29-7.20(\mathrm{~m}, 5 \mathrm{H}), 4.59$ (brs, $\left.1 \mathrm{H}\right), 3.55(\mathrm{~s}, 2 \mathrm{H})$, $3.06(\mathrm{~d}, J=8.8 \mathrm{~Hz}, 2 \mathrm{H}), 2.89(\mathrm{~m}, 1 \mathrm{H}), 2.39(\mathrm{~d}, J=8.8 \mathrm{~Hz}$, 2H), 1.39 (s, 9H), Mass: $m / z: 289.2(\mathrm{M}+\mathrm{H})^{+}$.

Synthesis of tert-butyl (1R, 5S, 6s)-3-azabicyclo[3.1.0]hexan-6-ylcarbamate (14): To a solution of compound 13 $(10 \mathrm{~g}, 34.72 \mathrm{mmol})$, in methanol $(100 \mathrm{~mL})$ was added $\mathrm{Pd}(\mathrm{OH})_{2}$ $(1 \mathrm{~g})$ and the reaction mixture was hydrogenated at 30 psi for $3 \mathrm{~h}$. After completion of reaction, filtered the reaction mass through celite bed and washed with methanol $(100 \mathrm{~mL})$. The solvent was distilled under vaccum and isolated the crude compound and thick mass. The crude mass was purified by column chromatography using $3 \%$ methanol/chloroform as an eluent to get pure compound $\mathbf{1 4}(5.8 \mathrm{~g}, 84 \%)$ as off-white solid. m.p. $109-112^{\circ} \mathrm{C}$; IR ( KBr, $\left.v_{\max }, \mathrm{cm}^{-1}\right): 3365,2935,1719$, 1690, 1529, 1249, 1164, 1050, 850 and 598; ${ }^{1} \mathrm{H}$ NMR (400 MHz, DMSO- $\left.d_{6}\right): \delta 6.83$ (brs, $\left.1 \mathrm{H}\right), 3.07-2.82(\mathrm{~m}, 4 \mathrm{H}), 2.23$ (s, 2H), 1.58-1.55 (m, 2H), $1.42(\mathrm{~s}, 9 \mathrm{H})$; Mass: $m / z: 199.1$ $(\mathrm{M}+\mathrm{H})^{+}$.

Preparation of amino compounds (15a and 15b): To a stirred solution of compound $\mathbf{5 a}$ (or) $\mathbf{5 b}(5 \mathbf{~ m m o l})$ in acetonitrile (10 vol) was added $\mathrm{K}_{2} \mathrm{CO}_{3}(15 \mathrm{mmol})$ and the solution of azabicyclo amine (compound 14) (5 mmol) at room temperature and heated at $80{ }^{\circ} \mathrm{C}$ for $4 \mathrm{~h}$. Upon completion, the reaction mixture filtered, concentrated and the residue was extracted with EtOAc. The combined organic layer was washed with water, brine solution, dried over anhydrous sodium sulfate, concentrated to afford the title compounds tert-butyl(1R,5S,6s)3-(2-methoxy-6-pentadecyl)-3-azabicyclo [3.1.0]hexan-6ylcarbamate (15a) and tert-butyl(1R, 5S, 6s)-3-(2-ethoxy-6pentadecyl)-3-azabicyclo[3.1.0]hexan-6-ylcarbamate (15b) as brown coloured oils. The crude compounds were taken to next step as such without further purification.

Preparation of amino compounds (16a and 16b): To a stirred solution of compound $\mathbf{1 5} \mathbf{a}$ or $\mathbf{1 5} \mathbf{b}$ in methanol was added methanolic $\mathrm{HCl}$ solution and stirred at room temperature for $6 \mathrm{~h}$. Upon completion, the reaction mixture was concentrated and the residue was diluted with water, basified with $\mathrm{NaHCO}_{3}$ solution, extracted with EtOAc $(2 \times 100 \mathrm{~mL})$. The combined organic layer was washed with water, brine solution, dried over anhydrous sodium sulfate, concentrated to afford the pure amino compounds (1R,5S,6s)-3-(2-methoxy-6pentadecylbenzyl)-3-azabicyclo[3.1.0]hexan-6-amine (16a) and (1R,5S,6s)-3-(2-ethoxy-6-pentadecylbenzyl)-3azabicyclo[3.1.0]hexan-6-amine (16b) as brown colour viscous oils. Compound 16a: IR (dichloromethane film, $\mathrm{cm}^{-1}$ ): 3366, 2923, 2853, 1674, 1587, 1461, 1260, 1085, 754; ${ }^{1} \mathrm{H}$ NMR $\left(400 \mathrm{MHz}, \mathrm{CDCl}_{3}\right): \delta 7.22-7.12(\mathrm{~m}, 1 \mathrm{H}), 6.80-6.70(\mathrm{~m}, 2 \mathrm{H})$, 4.01-3.40 (m, 5H), 3.1-2.80 (m, 2H), 2.90-2.60 (m, 3H), 2.281.25 (m, 28H), 0.87 (m, 5H); Mass: $m / z, 429.4(\mathrm{M}+\mathrm{H})^{+}$.; 16b: IR (dichloromethane film, $\mathrm{cm}^{-1}$ ): 3455, 2923, 2855, 1670, 1587, 1458, 1389, 1255, 1095, 750; ${ }^{1} \mathrm{H}$ NMR $(400 \mathrm{MHz}$, $\left.\mathrm{CDCl}_{3}\right): \delta$ 7.23-7.07 (m, 1H), 6.81-6.67 (m, 2H), 4.01-3.40 (m, 4H), 2.90-2.60 (m, 6H), 2.28-1.25 (m, 30H), 0.87 (m, 5H); Mass: $m / z 443(\mathrm{M}+\mathrm{H})^{+}$.

Preparation of amino compounds (17a and 17b): To a stirred solution of compound $\mathbf{8 a}$ (or) $\mathbf{8 b}(5 \mathrm{mmol})$ in acetonitrile (10 vol) was added $\mathrm{K}_{2} \mathrm{CO}_{3}(15 \mathrm{mmol})$ and the solution of azabicyclo amine (compound 14$)(5 \mathrm{mmol})$ at room temperature and heated at $80^{\circ} \mathrm{C}$ for $4 \mathrm{~h}$. Upon completion, the reaction mixture filtered, concentrated and the residue was extracted with EtOAc. The combined organic layer was washed with water, brine solution, dried over anhydrous sodium sulfate, concentrated to afford the crude amino compounds (17a and 17b). The crude compounds were taken to next step as such without further purification.

Preparation of amino compounds (18a and 18b): To a stirred solution of compound $\mathbf{1 7} \mathbf{a}$ or $\mathbf{1 7} \mathbf{b}$ in methanol was added methanolic $\mathrm{HCl}$ solution and stirred at room temperature for $6 \mathrm{~h}$. Upon completion, the reaction mixture was concentrated and the residue was diluted with water, basified with $\mathrm{NaHCO}_{3}$ solution, extracted with EtOAc $(2 \times 100 \mathrm{~mL})$. The combined organic layer was washed with water, brine solution, dried over anhydrous sodium sulfate, concentrated to afford the crude amino compounds methyl-2-(8-[(1R,5S,6s)-6amino-3-azabicyclo[3.1.0]hexan-3-yl]octyl-6-methoxybenzoate (18a) and ethyl-2-(8-((1R, 5S, 6s)-6-amino-3-azabicyclo [3.1.0]hexan-3-yl)octyl-6-ethoxybenzoate $(\mathbf{1 8 b})$ as brown colour viscous oils. Compound 18a: IR (DCM film, $\mathrm{cm}^{-1}$ ): 3368, 2929, 2855, 2789, 1730, 1588, 1462, 1267, 1109, 1072, 838, 740; ${ }^{1} \mathrm{H}$ NMR (400 MHz, $\left.\mathrm{CDCl}_{3}\right): 7.26(\mathrm{t}, J=8.2 \mathrm{~Hz}$, $1 \mathrm{H}), 6.81(\mathrm{~d}, J=7.6 \mathrm{~Hz}, 1 \mathrm{H}), 6.76(\mathrm{~d}, J=8.8 \mathrm{~Hz}, 1 \mathrm{H}), 3.90(\mathrm{~s}$, $3 \mathrm{H}), 3.81(\mathrm{~s}, 3 \mathrm{H}), 3.05-3.00(\mathrm{~m}, 1 \mathrm{H}), 2.52(\mathrm{t}, J=7.6 \mathrm{~Hz}, 2 \mathrm{H})$, 2.34-2.01 (m, 3H), 1.86-1.56 (m, 3H), 1.39-1.24 (m, 14H); Mass: $m / z 375(\mathrm{M}+\mathrm{H})^{+}$; 18b: IR (DCM film, $\left.\mathrm{cm}^{-1}\right)$ : 3386, 2981, 2928, 2858, 2788, 1726, 1588, 1461, 1265, 1109, 1067, 851, 753; ${ }^{1} \mathrm{H}$ NMR (400 MHz, $\left.\mathrm{CDCl}_{3}\right): 7.22(\mathrm{t}, J=8.2 \mathrm{~Hz}, 1 \mathrm{H})$, $6.79(\mathrm{~d}, J=7.6 \mathrm{~Hz}, 1 \mathrm{H}), 6.73(\mathrm{~d}, J=8.8 \mathrm{~Hz}, 1 \mathrm{H}), 4.39\left(\mathrm{q}, J_{1}=\right.$ $\left.7.2 \mathrm{~Hz}, J_{2}=14.4 \mathrm{~Hz}, 2 \mathrm{H}\right), 4.03\left(\mathrm{q}, J_{1}=6.8 \mathrm{~Hz}, J_{2}=14.0 \mathrm{~Hz}\right.$, $2 \mathrm{H}), 3.15-3.03(\mathrm{~m}, 1 \mathrm{H}), 2.54(\mathrm{t}, J=7.6 \mathrm{~Hz}, 2 \mathrm{H}), 2.35-2.31$ $(\mathrm{m}, 3 \mathrm{H}), 1.56-1.41(\mathrm{~m}, 3 \mathrm{H}), 1.39-1.25(\mathrm{~m}, 17 \mathrm{H})$; Mass: $\mathrm{m} / \mathrm{z}$ $403(\mathrm{M}+\mathrm{H})^{+}$.

Preparation of amino compounds (19a and 19b): To a stirred solution of compound $\mathbf{1 8 a}$ or $\mathbf{1 8 b}(1.0 \mathrm{mmol})$ in a mixture of THF and water (3:1) was added LiOH (1.0 mmol) and heated to reflux temperature for $6 \mathrm{~h}$. The THF was distilled out and the aqueous layer $\mathrm{pH}$ was adjusted to 4 range and extracted with EtOAc $(2 \times 100 \mathrm{~mL})$. The combined organic layer was washed with water, brine, dried over anhydrous sodium sulfate, concentrated to dryness and the crude product was purified by silica gel (100-200 mesh) column chromatography using ethyl acetate/pet ether as an eluent to afford the pure compounds 2-(8-((1R, 5S, 6s)-6-amino-3-azabicyclo [3.1.0]hexan-3-yl)octyl)-6-methoxybenzoic acid (19a) or 2-(8-[(1R,5S,6s)-6-amino-3-azabicyclo[3.1.0]hexan-3yl]octyl)-6-ethoxybenzoic acid 19b as thick brown coloured oily mass. Compound 19a: IR (DCM film, $\mathrm{cm}^{-1}$ ): 3340, 2929, 2855, 1656, 1464, 1266, 1085, 840, 749; ${ }^{1} \mathrm{H}$ NMR (400 MHz, $\mathrm{CDCl}_{3}$ ): 11.10 (br s, $\left.1 \mathrm{H}\right), 7.22(\mathrm{t}, J=8.0 \mathrm{~Hz}, 1 \mathrm{H}), 6.83(\mathrm{~d}, J=$ $8.0 \mathrm{~Hz}, 1 \mathrm{H}), 6.78(\mathrm{~d}, J=8.4 \mathrm{~Hz}, 1 \mathrm{H}), 3.81(\mathrm{~s}, 3 \mathrm{H}), 3.10-3.02$ $(\mathrm{m}, 1 \mathrm{H}), 2.54(\mathrm{t}, J=8.0 \mathrm{~Hz}, 2 \mathrm{H}), 2.38-1.99(\mathrm{~m}, 3 \mathrm{H}), 1.84-$ $1.51(\mathrm{~m}, 3 \mathrm{H}), 1.38-1.25(\mathrm{~m}, 14 \mathrm{H})$; Mass: $\mathrm{m} / \mathrm{z} 361(\mathrm{M}+\mathrm{H})^{+}$; 19b: IR (DCM film, $\mathrm{cm}^{-1}$ ): 3344, 2926, 2851, 1655, 1462, 1267, 1089, 842, 750; ${ }^{1} \mathrm{H}$ NMR (400 MHz, $\mathrm{CDCl}_{3}$ ): 11.2 (br $\mathrm{s}, 1 \mathrm{H}), 7.23(\mathrm{t}, J=8.0 \mathrm{~Hz}, 1 \mathrm{H}), 6.78(\mathrm{~d}, J=8.4 \mathrm{~Hz}, 1 \mathrm{H}), 6.72$ $(\mathrm{d}, J=8.4 \mathrm{~Hz}, 1 \mathrm{H}), 4.05\left(\mathrm{q}, J_{1}=6.6 \mathrm{~Hz}, J_{2}=13.8 \mathrm{~Hz}, 2 \mathrm{H}\right)$, 3.12-3.01 (m, 1H), $2.56(\mathrm{t}, J=7.6 \mathrm{~Hz}, 2 \mathrm{H}), 2.34-2.29(\mathrm{~m}$, 
3H), 1.53-1.42 (m, 3H),1.36-1.24 (m, 17H); Mass: $m / z, 375$ $(\mathrm{M}+\mathrm{H})^{+}$.

The synthesis of the azabicyclo amine analogues of anacardic acid (16a and 16b) was achieved by (i) Isolation and subsequent saturation of the ene-mixture of anacardic acid from commercially available CNSL (ii) Alkylation of the phenolic hydroxyl group and esterfication of carboxylic acid group (iii) Reduction of the ester to alcohol (iv) Transformation of the alcohol to its mesylate ( $\mathrm{v}$ ) Coupling of mesylate compound with azabicyclo[3.1.0]amine to afford the novel azabicyclo analogues of anacardic acid (vi) cleavage of boc protection to afford the free amine and screening for their antibacterial activity as depicted Scheme-I.

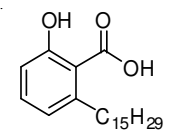

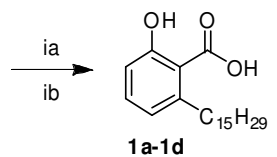

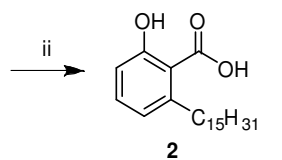

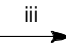

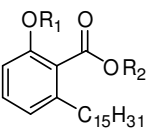

3a $\left(R_{1} \& R_{2}=M e\right)$ $3 b\left(R_{1} \& R_{2}=E t\right)$
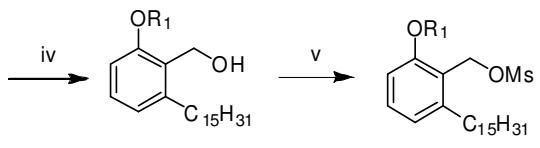

$$
\begin{aligned}
& \mathbf{4 a}\left(R_{1}=M e\right) \\
& \mathbf{4 b}\left(R_{1}=E t\right)
\end{aligned}
$$$$
5 \mathbf{a}\left(\mathrm{R}_{1}=\mathrm{Me}\right)
$$$$
\mathbf{5 b}\left(R_{1}=E t\right)
$$

Reagents: (ia) $\mathrm{Ca}(\mathrm{OH})_{2}, \mathrm{MeOH}: \mathrm{H}_{2} \mathrm{O}(5: 1), 60^{\circ} \mathrm{C}, 3 \mathrm{~h}$, (ib) $6 \mathrm{~N} \mathrm{HCl}$, (ii) $10 \%$ $\mathrm{Pd} / \mathrm{C}, \mathrm{H}_{2}$, EtOH, 60 psi, rt, $2 \mathrm{~h}$; (iii) $\left(\mathrm{CH}_{3}\right)_{2} \mathrm{SO}_{4} /\left(\mathrm{C}_{2} \mathrm{H}_{5}\right) 2 \mathrm{SO}_{4}, \mathrm{~K}_{2} \mathrm{CO}_{3}, \mathrm{CH}_{3} \mathrm{CN}$, $80{ }^{\circ} \mathrm{C}, 3 \mathrm{~h}$ (iv) $\mathrm{LiAlH}_{4}$, THF, $0{ }^{\circ} \mathrm{C}$-rt, $16 \mathrm{~h}$ (v) $\mathrm{CH}_{3} \mathrm{SO}_{2} \mathrm{Cl},\left(\mathrm{C}_{2} \mathrm{H}_{5}\right)_{3} \mathrm{~N}, \mathrm{CH}_{2} \mathrm{Cl}_{2}$, $0{ }^{\circ} \mathrm{C}-\mathrm{rt}, 3 \mathrm{~h}$

\section{Scheme-I}

Isolation of the anacardic acid ene-mixture (Fig. 1, 1a-d) from commercially available cashew nut shell liquid was carried out by treating with $\mathrm{Ca}(\mathrm{OH})_{2}$ in a $\mathrm{MeOH}-\mathrm{H}_{2} \mathrm{O}$ mixture at $50{ }^{\circ} \mathrm{C}$ for $3 \mathrm{~h}$ followed by filtration of calcium anacardate as a brown coloured solid. This solid was treated with $6 \mathrm{~N} \mathrm{HCl}$ to obtain the anacardic acid ene-mixture as a dark brown coloured oily liquid. The ene-mixture was the saturated by hydrogenolysis using $\mathrm{Pd} / \mathrm{C}-\mathrm{H}_{2}$ in EtOH under 60 psi of hydrogen pressure at room temperature to afford the anacardic acid (2) as a pale brown coloured solid which was then alkylated with dimethylsulphate (or) diethylsulphate and $\mathrm{K}_{2} \mathrm{CO}_{3}$ in acetonitrile at reflux temperature. The 2-methoxy methyl ester (or) ethoxy ethyl ester of anacardic acid (3a or $\mathbf{3 b}$ ) was reduced with $\mathrm{LiAlH}_{4}$ in THF at room temperature for $16 \mathrm{~h}$ to afford the corresponding benzyl alcohol (4a or $\mathbf{4 b}$ ), which was then transformed to its methane sulfonate esters $(\mathbf{5} \mathbf{a}$ or $\mathbf{5 b})$ by treatment with methane sulfonyl chloride and triethylamine in dichloromethane at $0{ }^{\circ} \mathrm{C}$ (Scheme-I).

The synthesis of bromo derivatives of anacardic acid (8a and $\mathbf{8 b}$ ) were achieved by i) Isolation of ene-mixture of anacardic acid from commercially available CNSL; ii) Alkylation of the phenolic hydroxyl group and esterfication of carboxylic acid group; (iii) a) Ozonolysis of alkene (ene-mixture) to afford the C-8 aldehyde b) reduction of aldehyde to alcohol (in situ) (iv) Transformation of the alcohol to its bromo derivative (Scheme-II).

The azabicyclo[3.1.0]amine was synthesized as per the reported procedures ${ }^{17}$ as depicted in Scheme-III. The synthesis of azabicyclo amine was achieved by (i) treatment of $N$-benzyl maleimide with bromonitromethane (ii) reduction of Imide
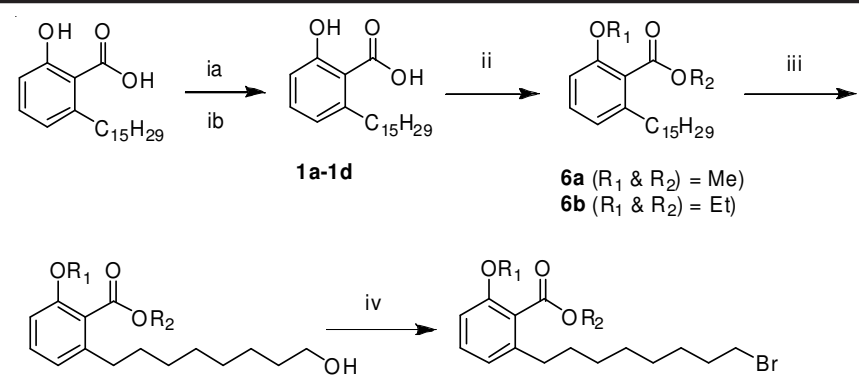

$$
\begin{array}{ll}
\left.7 \mathbf{a}\left(R_{1} \& R_{2}\right)=M e\right) & \left.\mathbf{8 a}\left(R_{1} \& R_{2}\right)=M e\right) \\
\left.\mathbf{7 b}\left(R_{1} \& R_{2}\right)=E t\right) & \left.\mathbf{8 b}\left(R_{1} \& R_{2}\right)=E t\right)
\end{array}
$$

Reagents: (ia) $\mathrm{Ca}(\mathrm{OH})_{2}, \mathrm{MeOH}: \mathrm{H}_{2} \mathrm{O}(5: 1), 60^{\circ} \mathrm{C}, 3 \mathrm{~h}$, (ib) $6 \mathrm{~N} \mathrm{HCl}$, (ii) Dimethyl sulfate (or) Diethyl sulfate, $\mathrm{K}_{2} \mathrm{CO}_{3}$, Acetonitrile, $90{ }^{\circ} \mathrm{C}, 24 \mathrm{~h}$; (iii) a) $\mathrm{O}_{3}, \mathrm{MeOH}$ :DCM (1:1), $-78{ }^{\circ} \mathrm{C}, 4 \mathrm{~h}$ (b) $\mathrm{NaBH}_{4}, \mathrm{rt}, 16 \mathrm{~h}$; (iv) $\mathrm{CBr}_{4}, \mathrm{PPh}_{3}$, Pyridine, DCM, rt, 16 h

\section{Scheme-II}

with Borane. THF solution (iii) reduction of nitro group using zinc dust and conc. $\mathrm{HCl}$ (iv) Protection of amine using Boc anhydride (v) $N$-debenzylation using $\mathrm{Pd}(\mathrm{OH})_{2}$ and $\mathrm{H}_{2}(\mathrm{~g})$ (Scheme-III).

The synthesis of the azabicyclo[3.1.0]amine analogues of anacardic acid were achieved by (i) coupling of mesylate compounds ( $\mathbf{5} \mathbf{a}$ and $\mathbf{5 b}$ ) with compound $\mathbf{1 4}$ to afford the novel azabicyclo analogues of anacardic acid (15a and 15b) (ii) cleavage of boc protection to afford the free amines (16a and 16b) (Scheme-IV).

The synthesis of the azabicyclo[3.1.0]amine analogues of anacardic acid (18a and 18b) were achieved by (i) coupling of bromo derivatives of anacardic acid (8a and 8b) with compound $\mathbf{1 4}$ to afford the novel azabicycloamine analogues of anacardic acid (17a and $\mathbf{1 7 b}$ ) (ii) cleavage of boc protection of $17 \mathbf{a}$ and $\mathbf{1 7 b}$ to afford the free amines $18 \mathbf{a}$ and $\mathbf{1 8 b}$ respectively (iii) Hydrolysis of $\mathbf{1 8 a}$ and $\mathbf{1 8 b}$ to afford the carboxylic acids (19a and 19b) (Scheme-V).

\section{RESULTS AND DISCUSSION}

To generate the lead molecules compounds $\mathbf{5 a}, \mathbf{5 b}, \mathbf{8 a}$ and $\mathbf{8 b}$ compounds were coupled with azabicyclo[3.1.0]amine (14) to afford novel azabicyclo[3.1.0]amine analogues of anacardic acid to afford compounds 16a, 16b, 18a and 18b. Compounds 18a and $\mathbf{1 8 b}$ were hydrolyzed to afford compounds 19a and 19b.

In order to evaluate the antibacterial activity, compounds 16a, 16b, 18a, 18b, 19a and 19b were screened for in vitro activity against $S$. aureus and $S$. pyogens (Gram positive (G $+\mathrm{ve})$ ) and $E$. coli and $P$. aeruginosa (Gram negative (G-ve)) groups of bacteria.

The compounds 16a, 16b, 18a, 18b, 19a and 19b were dissolved in dimethyl sulphoxide at $250 \mu \mathrm{g} / \mathrm{mL}$ concentration. The composition of nutrient agar medium was bactotryptone $(10 \mathrm{~g})$, yeast extract $(5 \mathrm{~g}), \mathrm{NaCl}(10 \mathrm{~g})$, final $\mathrm{pH}$ was 7.4. After $18 \mathrm{~h}$ the exponentially growing cultures of the bacteria in nutrient broth at $37^{\circ} \mathrm{C}$ were diluted in sterile broth. From each of these diluted cultures, $1 \mathrm{~mL}$ was added to $100 \mathrm{~mL}$ of sterilized and cooled nutrient agar media to give the final bacterial count of $1 \times 10^{6}$ cell $/ \mathrm{ml}$. Paper discs $(6 \mathrm{~mm}$, punched from Whatmann no. 41 paper) were ultraviolet and used for assays. Discs were soaked in different concentrations of the test 
<smiles>CN(C)c1ccccc1</smiles><smiles>N[C@H]1[C@@H]2CN(Cc3ccccc3)C[C@H]12</smiles>

12
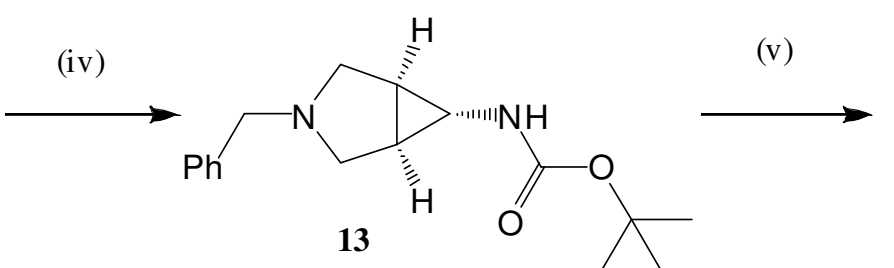

Reagents: (i) Bromonitromethane, $\mathrm{K}_{2} \mathrm{CO}_{3}$, Acetonitrile, rt, 4 h; (ii) Borane THF complex, THF, $65{ }^{\circ} \mathrm{C}, 3$ h; (iii) $\mathrm{Zn}$ dust, $1 \mathrm{~N} \mathrm{HCl}$, Isopropyl alcohol, rt, 2 h; (iv) $(\mathrm{BOC})_{2} \mathrm{O}$, TEA, DCM, $0{ }^{\circ} \mathrm{C}-\mathrm{rt}, 4 \mathrm{~h}$; (v) $\mathrm{Pd}(\mathrm{OH})_{2}, \mathrm{H}_{2}, \mathrm{EtOH}, \mathrm{rt}, 50 \mathrm{psi}, 4 \mathrm{~h}$

Scheme-III<smiles>CC(C)(C)OC(=O)N[C@H]1C2CNC[C@@H]21</smiles>

Triethylamine, acetonitrile, $85{ }^{\circ} \mathrm{C}, 3 \mathrm{~h}$<smiles>CCCCCCCCCCCCCCCc1cccc(OCC)c1COC</smiles>

$5 \mathbf{a}\left(R_{1}=M e\right)$ $\mathbf{5 b}\left(\mathrm{R}_{1}=\mathrm{Et}\right)$
$15 \mathbf{a}\left(\mathrm{R}_{1}=\mathrm{Me}\right)$

15b $\left(R_{1}=E t\right)$<smiles>CCCCCCCCCCCCCCCc1cccc(O)c1CN1C[C@@H]2C(N)[C@H]2C1</smiles>

$\mathrm{HCl}(\mathrm{g})$ in $\mathrm{MeOH}$, r.t, $12 \mathrm{~h}$<smiles>CCCCCCCCCCCCCCCc1cccc(O)c1CN1C[C@@H]2[C@H](C1)[C@@H]2NC(=O)OC(C)(C)C</smiles>

Scheme-IV

solution and placed on the inoculated agar media at regular intervals of 6-7 cm. Care was taken to ensure that excess solution was not on the discs. All samples were taken in triplicates. The plates were incubated at $37{ }^{\circ} \mathrm{C}$ in an inverted fashion. Activity was determined by measuring the zones showing the inhibition (mm). Growth inhibition was calculated with reference to positive control.

When the compounds were screened against $E$. coli molecules 16a and 16b displayed very good activities $(15 \mathrm{~mm}$ zone of inhibition) at par with ampicillin while other molecules 19a and 19b exhibited moderate activity ( $14 \mathrm{~mm}$ zone of inhibition) and compounds 18a and 18b have shown inferior activity. Similarly, when the compounds were screened against $P$. aeruginosa, almost all the compounds displayed moderate activity compared to ampicillin and other standard drugs.

On screening against $S$. aureus, 16a, 16b, 19a and 19b have displayed at par activity with ampicillin and 18a and 18b displayed moderated activity. Similarly, when the compounds were screened against $P$. aeruginosa, almost all the compounds displayed moderate activity compared to ampicillin and other standard drugs and the in vitro results are summarized in Table-1. 
<smiles>CCOC(=O)c1c(CCCCCCCCBr)cccc1OCC</smiles>

$8 \mathbf{a}\left(R_{1} \& R_{2}=M e\right)$

$8 b\left(R_{1} \& R_{2}=E t\right)$<smiles>CC(C)(C)OC(=O)NC1[C@H]2CNC[C@H]12</smiles>

Triethylamine, acetonitrile, $85^{\circ} \mathrm{C}, 3 \mathrm{~h}$

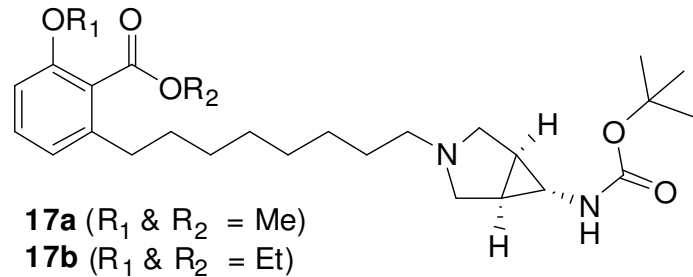<smiles>CCCCCCc1cccc(OCC)c1C(=O)OCCCCCC(C)(C)C</smiles>

$18 b\left(R_{1} \& R_{2}=E t\right)$<smiles>CCCCN1C[C@H]2[C@H](N)[C@H]2CN(CCCCCCCc2cccc(OCC)c2C(=O)O)C1</smiles>

Scheme-V

\section{TABLE-1}

ANTIMICROBIAL ACTIVITY OF COMPOUNDS ANTIMICROBIAL ACTIVITY (ZONE OF INHIBITION IN mm)

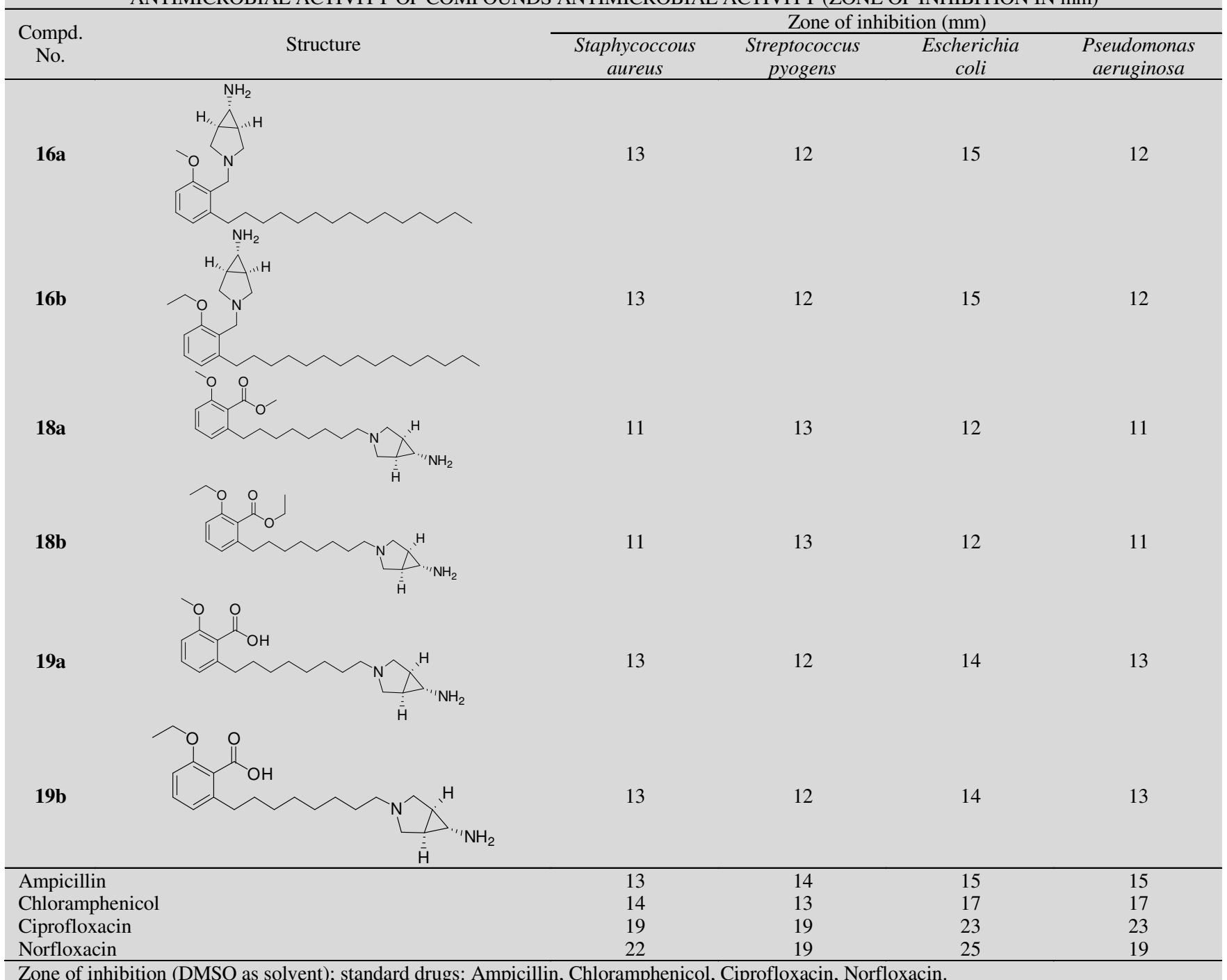

Zone of inhibition (DMSO as solvent); standard drugs: Ampicillin, Chloramphenicol, Ciprofloxacin, Norfloxacin 


\section{Conclusion}

Novel azabicyclo[3.1.0]amine analogues of anacardic acid were synthesized and screened for their antibacterial activity. Few analogues displayed activities at par with Ampicillin and all the analogues displayed moderate activity compared to other standard drugs.

\section{ACKNOWLEDGEMENTS}

The author thank GVKBIO Sciences Pvt. Ltd. for financial support. Thanks are also due to Dr. Balaram Patro, Dr. Joseph, Dr. Ravi Kumar for their constant support and encouragement.

\section{REFERENCES}

1. R. Paramshivappa, P.P. Kumar, P.J. Vijayathil and A.S. Rao, J. Agric. Food Chem., 49, 2548 (2001).

2. P.P. Kumar, R. Paramshivappa, P.J. Vijayathil, P.V.S. Rao and A.S. Rao, J. Agric. Food Chem., 50, 4705 (2002).

3. I. Kubo, H. Muroi and M. Himejima, J. Agric. Food Chem., 41, 1016 (1993).

4. I. Kubo, K. Nihei and K. Tsuzimoto, J. Agric. Food Chem., 51, 7624 (2003).

5. J. Rejman and A. Kozubek, J. Agric. Food Chem., 52, 246 (2004)

6. I. Kubo and T.J. Ha, J. Agric. Food Chem., 53, 4350 (2005).
7. R. Paramshivappa, P.P. Kumar, P.V.S. Rao and A.S. Rao, J. Agric. Food Chem., 50, 7709 (2002)

8. (a) P.P. Kumar, R. Paramshivappa, P.V.S. Rao and A.S. Rao, PCT WO 105854 A2 (2003). (b) P.P. Kumar, R.Paramshivappa, P.V.S. Rao and A.S. Rao, PCT WO 062201 A1 (2003).

9. B.N. Swamy, T.K. Suma, C.V. Rao and G.C. Reddy, Eur. J. Med. Chem., 42, 420 (2007).

10. D.J. Schultz, C. Olsen, G.A. Cobbs, N.J. Stolowich and M.M. Parrott, J. Agric. Food Chem., 54, 7522 (2006).

11. B. Sung, K.P. Manoj, K.S. Ahn, T. Yi, M.M. Chaturvedi, M. Liu and B.B. Agarawal, Blood, 111, 4880 (2008).

12. I. Kubo, M. Ochi, P.C. Viera and S. Komastu, J. Agric. Food Chem., 41, 1012 (1993).

13. P. Begum, Y. Hashidoko, Md. T. Islam, Y. Ogawa and S. Tahara, Z. Naturforsch, 57c, 874 (2002).

14. A. Harikishore, B.M. Vedamurthy, K. Mantelingu, S. Agarwal, B.A. A. Reddy, S. Roy, K.S. Rangappa and T.K. Kundu, J. Med. Chem., 51, 792 (2008)

15. V. Chandregowda, A. Kush and G.C. Reddy, Eur. J. Med. Chem., 44, 2711 (2009).

16. R.K. Vempati, N.S. Reddy, S.R. Alapati and P.K. Dubey, Der Pharma Chem., 3, 500 (2011)

17. (a) T. Norris, T.F. Braish, M. Butters, K.M. Devries, J.M. Hawkins, S.S. Masset and P.R. Rose, D. Santafianos and C. Sklavounos, J. Chem. Soc., Perkin Trans. I, 1615 (2000); (b) Q. Sun, R. Zhu, F.W. Foss Jr. and T.L. Macdonald, Bioorg. Med. Chem. Lett., 17, 6682 (2007); (c) G. Madhusudan, V. Balaraju, T. Rajesh, B.V. Narayana and R.N. Reddy, Indian J. Chem., 48B, 569-573 (2009). 